\title{
The disciplinary Responsibility of the Polish PHYSICIANS AND DENTISTS FOR PROFESSIONAL DELINQUENCIES COMMITTED ABROAD
}

\begin{abstract}
The subject of the study is the analysis of the issue of disciplinary responsibility of the Polish physicians and dentists for professional delinquencies committed abroad. The research goal is to find the answer to the question: is it possible in the Polish legal system to derive negative legal consequences for a physician or a dentist, who has the Polish right to practice the profession, in a situation where a violation of the law in another country is found. The article uses primarily the method of logical and linguistic analysis of Polish legal acts. An analysis of the available literature in this area was made. Empirical research methods were also used, including the examination of documents within Polish medical chambers, containing information on members of the Polish professional self-government punished abroad. The research shows that from 2016 until the first half of 2020 the Polish professional self-government has learned about the punishment in other Member States of 61 members of Polish medical chambers, of which 52 were punished in the United Kingdom, 4 in Sweden, 2 in Ireland, 1 in Denmark, 1 in Germany, 1 in Finland. The final conclusion of the study is that it is possible to derive negative legal consequences for a physician or a dentist, who has the Polish right to practice the profession, in a situation where a violation of the law has been found in another country.
\end{abstract}

KeYwORDs: disciplinary responsibility of physicians and dentists, Internal Market Information System, alert mechanism, professional delinquencies committed abroad, European Union 


\section{INTRODUCTION}

The profession of physician and dentist is a profession of public trust (Izdebski, 2002, p. 34). The special status of a physician and a dentist obliges to provide medical services of the highest quality, while maintaining high ethical and moral standards. Violation of the principles of the profession's deontology is connected with the disciplinary responsibility of a physician and a dentist. Disciplinary liability is a separate form of legal liability and functions alongside criminal (Rejman, 1991), or civil liability (Zielińska, 2001, p. 9). The legal base for disciplinary liability is determined by the regulations related to the exercise of the profession of physician and dentist and the rules of medical ethics (Liszewska, 2016, p. 427). In accordance with article 53 of the Law Act of 2 December 2009 on Chambers of Physicians and Dentists (consolidated text - Journal of Laws of 2019, item 965, hereinafter: c.p.d.), members of medical chambers are subject to disciplinary liability for violation of the rules of medical ethics and regulations related to the exercise of the profession. The principles of medical ethics (Rużyło, E. 1999) have been formulated in the Code of Medical Ethics (hereinafter c.m.e.). Regulations related to the exercise of the profession can be found in a number of normative acts, which include, among others: the Law Act of 5 December 1996 on the professions of physician and dentist (consolidated text - Journal of Laws of 2020, item 514). The proper exercise of the profession of physician and dentist is supervised by the professional self-government bodies (screeners for professional liability and medical courts), which is enshrined in article 17 of the Constitution of the Republic of Poland (Sobczak, 2015, pp. 39-40). The subject of this publication will be the issue of disciplinary responsibility of a physician and a dentist for delinquencies committed outside the Republic of Poland. The literature on the subject has not yet analysed this issue in detail. Cross-border practice of the profession of a physician and a dentist is a natural phenomenon in the era of globalization. Therefore, the question should be asked whether it is possible in the Polish legal system to derive negative legal consequences for a physician or a dentist, who has the Polish right to practice the profession, in a situation where a violation of the law in another country is found. In order to answer this question, it is necessary to analyse whether in each case of a foreign medical court imposing sanctions, 
actions should be taken by the Polish professional self-government bodies. It is also necessary to answer the question whether it is permissible for a medical court in Poland to take over for enforcement the judgement of the foreign medical court and if so, in what cases.

The article uses primarily the method of logical and linguistic analysis of legal acts in particular the Law Act of 6 June 1997 Code of Criminal Procedure (consolidated text - Journal of Laws of 2020, item 30, hereinafter: c.c.p.), the Law Act of 6 June 1997 Criminal Code (consolidated text - Journal of Laws of 2020, item 1444, hereinafter: c.c.) and the Law Act of 2 December 2009 on Chambers of Physicians and Dentists (consolidated text - Journal of Laws of 2019, item 965, hereinafter: c.p.d.). An analysis of the available literature in this area and empirical researches methods were also used.

\section{THE SCOPE OF DISCIPLINARY RESPONSIBILITY AND THE PROCEDURE FOR THE PROFESSIONAL LIABILITY OF A PHYSICIAN AND A DENTIST}

The scope of disciplinary responsibility of a physician and a dentist is wide. Disciplinary liability is not limited to the obligation to comply with generally applicable law. In accordance with article 76 of the c.m.e., in cases not provided for in the Code of Medical Ethics, the physician should be guided by the principles expressed in resolutions of medical self-government authorities, jurisprudence of medical courts, good manners adopted by the medical community (Gubiński, 1993, p. 7). Moreover, according to art. 1, paragraph 3 of the c.m.e., the dignity of the profession is violated by any conduct of a physician that undermines confidence in the profession.

The procedure for disciplinary responsibility is defined in chapter 5 of c.p.d. It should be emphasised that the organizational bodies of the professional self-government in Poland include 24 regional chambers and Supreme Chamber. Every physician and dentist authorized to practice the profession in Poland is a member of one of the regional chambers by virtue of the law. Each complaint, which refers to a member of one of the regional chambers is considered by the screener for professional liability (a prosecutor in the professional self-government of physicians and dentists) who may issue 
a decision to initiate an investigation if, in his opinion, there are circumstances justifying the possibility of committing a professional misconduct. Surveys conducted on the premises of medical chambers indicate that within one year about 3,000 information about the possibility of committing a professional misconduct is sent to screeners for professional liability throughout Poland. If, in the course of the investigation, it turns out, on the basis of the evidence gathered, that the act constitutes a professional misconduct, the screener for professional liability sends a motion for punishment to the regional medical court (Wrześniewska-Wal, 2018). The proceedings before the medical courts are two-instance. The parties are entitled to appeal against the ruling of the regional medical court to the Supreme Medical Court.

The analysis of the regulations of the c.p.d. leads to the conclusion that medical disciplinary liability is very similar to criminal liability. It should be repeated after Eleonora Zielińska that the disciplinary responsibility of a physician and a dentist is similar to the criminal responsibility (it is even considered quasi-criminal responsibility), if only in the sense that the competent authorities can impose on a person a sanction which is a form of state coercion (Zielińska, 2001, pp. 9, 91). It should be emphasized that a medical court can impose very serious sanctions, including disqualification from practicing (erasure from the register). In view of the above, it can be concluded that disciplinary responsibility is repressive too. In addition it should be stressed that according to article 112, paragraph 1 of the c.p.d. in cases not regulated by the c.p.d. the provisions of the Code of Criminal Procedure apply mutatis mutandis, with some exceptions. Furthermore, the legislature referred in art. 112, paragraph 2 of the c.p.d. to the appropriate application of chapters 1-3 of the c.c., which regulate the general principles of criminal liability, the provisions defining the circumstances excluding guilt, as well as article 53 of the c.c. relating to the directives on the level of punishment, apply accordingly (Nowacki, 1964, p. 372).

On the basis of the above mentioned provisions of the Code of Criminal Procedure and of the Criminal Code, a definition of professional misconduct can be formulated, according to which professional misconduct is an act of a physician or dentist, unlawful, socially harmful and culpable (Jóźwiak, 2016, p. 166). A physician's act in the context of disciplinary liability shall be 
understood to mean both an act (e.g., leaving a foreign body in the operating field) and an omission (e.g., failure to assist a patient) (Gardocki, 2019, p. 8). It should be remembered that a professional misconduct is a culpable act, and the proper application of the Criminal Code allows for the application of rules excluding guilt in the case of medical disciplinary liability (Jóźwiak, 2016, p. 166). Despite many similarities between criminal liability and disciplinary liability, it should be pointed out that there are fundamental differences between them. In the case of disciplinary liability, the principle of nullum crimen sine lege, which is fundamental for criminal proceedings, will not directly apply. In the case of professional liability, we are not dealing with a closed catalogue of professional misconducts. It should be reiterated that according to art. 1, paragraph 3 c.m.e., any behaviour that undermines confidence in the profession is a violation of the dignity of the profession. It is also worth emphasizing that there are no specific sanctions for particular professional misconduct, as it is the case in the c.c. It should be pointed out that art. 53 of the c.p.d. does not limit liability to acts committed on the territory of the Republic of Poland. Criminal liability is based on the principle of territoriality. In accordance with art. 5 of the c.c., the Polish Criminal Law applies to the perpetrator who committed a prohibited act on the territory of the Republic of Poland, as well as on a Polish ship or aircraft, unless an international agreement to which the Republic of Poland is a party provides otherwise. As Przemysław Konieczniak points out in the context of the proper application of article 5 of the c.c. in the professional liability of physicians, "At first glance, the conclusion is drawn that in this case the disciplinary liability of physicians does not cover acts committed abroad at all (...)" (Konieczniak, 2016, pp. 696-697). Nevertheless, in the opinion of the author, such a view "Causes anxiety because of its functional effects. It will then turn out, for example, that a physician of Polish citizenship, who has performed therapeutic activities abroad unprofessionally (contrary to the indications of the current state of knowledge or carelessly), in addition to the detriment of another Polish citizen, has not committed a professional misconduct within the meaning of c.p.d" (Konieczniak, 2016, pp. 696-697). But why did he not commit it if the current state of knowledge in medicine is the same in Poland and abroad, including in areas not subject to any jurisdiction? There is no 
doubt that certain principles of ethics, or due diligence in the exercise of the profession remain universal, regardless of the place of the profession. The broad scope of professional responsibility, on the other hand, entitles to state that it is permissible, on the basis of Polish national regulations, to declare the disciplinary responsibility of a physician and a dentist for acts taking place outside the territory of the Republic of Poland.

\section{THE CURRENT MODEL OF CONDUCT OF MEDICAL AUTHORITIES OF PROFESSIONAL SELF-GOVERNMENT IN THE CASE OF RECEIVING INFORMATION ABOUT PUNISHMENT OF A POLISH PHYSICIAN OR DENTIST BY A FOREIGN MEDICAL COURT}

The bodies of medical self-government in Poland are increasingly receiving information from other European Union Member States about physicians and dentists who have been restricted or suspended from practicing their profession in those countries (Kowalski, 2017, pp. 696-697). Some of this information concerns physicians or dentists who have the right to practice their profession in Poland. The research shows that from 2016 until the first half of 2020, through the Internal Market Information System (hereinafter: IMI) by alert mechanism, the professional self-government of physicians and dentists in Poland has learned about the punishment in other Member States of 61 members of Polish medical chambers, of which 52 were punished in the UK (Zamroczyńska, 2018, pp. 29-36), 4 in Sweden, 2 in Ireland, 1 in Denmark, 1 in Germany, 1 in Finland.

It is worth noting that in not all countries the disciplinary responsibility of physicians is exercised within the professional self-government. For example, in countries such as: Cyprus, Denmark, Estonia, Finland, Ireland, Malta, the Netherlands, Norway, Sweden, the United Kingdom, Iceland, the recognition of cases of disciplinary responsibility is the responsibility of government administration bodies. The countries where the professional responsibility of physicians is dealt with by professional self-governments, as it is the case in Poland, include, among others Austria, Belgium, Bulgaria, Croatia, Czech Republic, France, Germany, Italy, Portugal, Romania, Slovenia, Spain. 
The decisions issued can be divided into those that could be classified as professional misconducts according to Polish law and those that were not. The first group includes: practicing the profession contrary to the indications of current medical knowledge, failure to exercise due diligence in undertaken medical activities, irregularities in keeping medical records, falsification of medical records. The second group includes several situations in which Polish physicians were restricted or suspended from exercising their profession in United Kingdom due to insufficient knowledge of English. An analysis of the protocols of the British Medical Practitioners Tribunal Service shows that physicians had difficulties in conducting medical interviews with British patients. Other physicians complained about the difficulties in communicating with the defendants. They were required to pass additional tests and exams to verify their English. The analysis of Polish regulations related to the profession and c.m.e. leads to the conclusion that a physician's insufficient knowledge of English could not be the basis for his disciplinary responsibility in Poland. It follows from the above that not every case of sanctions imposed by a foreign medical court should be dealt with by the Polish professional self-government bodies.

Information concerning a physician or dentist who has had his or her professional rights limited in the Member States of the European Union or who has been temporarily or permanently deprived of such rights is transmitted through the "alert mechanism" established by the European Commission. The "alert mechanism" is an electronic tool that allows the IMI to exchange information between Member States on any suspension or restriction of the right to practise as a physician or dentist (Szewczyński, Tomaszewska, 2017, pp. 30-31). The system can be accessed by the competent authorities of individual Member States. In Poland such authorities are regional medical chambers. The obligation to provide this information results from article 56a of Directive 2005/36/EC of the European Parliament and of the Council of 7 September 2005 on the recognition of professional qualifications (Official Journal of the European Union, WE L 255. 30.09.2005 ).

In 2018 the Supreme Screener for Professional Liability (the prosecutor in the professional self-government supervising the other regional 
prosecutors) decided to take an action in Poland relying on judgement of the British Medical Practitioners Tribunal Service. The case concerned a physician with the right to practice in Poland, punished on the territory of the United Kingdom for, inter alia, numerous medical errors, including failure to exercise due diligence in diagnostic, therapeutic and preventive proceedings. Pursuant to article 608, paragraph 2 of the c.c.p. in the case of a legally binding ruling by a court of a foreign country against a person conducting professional activity in the territory of the Republic of Poland, prohibition to pursue a specific profession, the Minister of Justice may apply to the competent authority of that country to take over for enforcement the judgement of the foreign medical court in the Republic of Poland. By means of appropriate application of art. 112, paragraph 1 of the c.p.d. in the case of a legally binding ruling prohibiting a foreign medical court from practising the profession of a physician, if the physician has the right to practise the profession also in Poland, it is possible to take over for enforcement the judgement of the foreign medical court in Poland (Urbaniak, 2018). The Supreme Screener for Professional Liability is a body whose powers in the self-governing structure are in a sense similar to those of the Minister of Justice (Tomaszewska, 2019, p. 176). That is why Supreme Screener for Professional Liability is entitled to apply to polish medical court to take over the judgement of the foreign medical court in Poland, pursuant to art. 608 c.c.p. The Regional Medical Court has accepted the motion of the Supreme Screener for Professional Liability applying to taking over the judgement of the British medical court in Poland. This decision was appealed. The Supreme Medical Court, recognizing the appeal, upheld the decision of the first instance court.

In my opinion, in order to resolve any doubts as to the mode of bearing disciplinary responsibility for acts committed abroad, this issue should be regulated directly in the provisions of c.p.d. This will allow for more efficient conduct of proceedings in such situations. The c.p.d. does not explicitly include legal regulations allowing for a reaction of the professional selfgovernment bodies in Poland in case of punishing a physician or a dentist abroad. In the scope not regulated by the provisions of the Act, appropriate application of the provisions of the Code of Criminal Procedure, including 
the provisions of Chapter 66 of the c.c.p. (Janicz, 2020, Augustyniak, 2019), is permitted in terms of taking over the judgement of foreign medical court decisions (Tomaszewska, 2019, p. 161-179).

The lack of adequate legal regulations in this area was also pointed out in 2018, in an deputy interpelation No. 18939 to the Minister of Health on the failure to regulate the possibility of taking over for enforcement the judgement of the foreign medical court in Poland. In particular, the interpelation indicated that an unambiguous regulation of the above issue would allow for the realization of the public interest by the professional self-government. In response to the interpelation, it was noted that if a physician commits a professional misconduct outside Poland, it is possible to conduct an investigation under the provisions of chapter 5 of the c.p.d.-

However, conducting separate proceedings by a medical court in connection with a member of the Polish Medical Chamber's professional misconduct outside Poland is associated with many difficulties. The investigation would involve the translation of medical records, which would significantly increase costs of disciplinary proceeding. It should also be remembered that procedural deadlines must be kept. Pursuant to art. 64, paragraph 1 of the c.p.d., proceedings on disciplinary liability cannot be initiated if 3 years have passed since the act was committed. In the light of the art. 64, paragraph 3 of the c.p.d., the punishability of a professional misconduct ceases if 5 years have passed since the act was committed.

\section{THE DRAFT AMENDMENTS TO THE LAW ACT of 2 December 2009 On Chambers of Physicians AND DENTISTS CONCERNING THE PROCEDURE FOR PUNISHMENT OF PHYSICIANS AND DENTISTS ABROAD}

Due to the growing amount of information about members of Polish medical chambers punished abroad, on 25 January 2019. the Supreme Medical Chamber issued a resolution on the preparing a draft amendments to the Law Act of 2 December 2009 on Chambers of Physicians and Dentists concerning the procedure for punishment of physicians and dentists abroad. 
This draft was prepared and developed by Teresa Gardocka, professor SWPS University of Humanities and Social Sciences in Warsaw. Unfortunately, the proposed solutions have not been implemented into the Act to this day. The project introduces a legal institution, the so-called acceptance for execution in Poland of sentences passed abroad against a physician who is also a member of the Polish Medical Chamber. It is proposed to add to the c.p.d. chapter 5a devoted to the subject matter: "acceptance of penalty imposed by medical court abroad".

Article 112a of the draft indicates that "A punishment imposed abroad against a member of the Polish regional chamber may be accepted for taking over for enforcement in the Republic of Poland. As a body entitled to apply to the competent authority of a foreign country to submit a copy of the decision together with a justification, the Supreme Screener for Professional Liability is indicated in art. $112 \mathrm{~b}$ of the draft. In order to accept a penalty to be enforced, the following conditions must be met: a given judgment is final and enforceable, the act constitutes a professional misconduct also according to Polish law, a physician who committed a professional misconduct would be subject to a penalty also in Poland, there is no statute of limitations for the enforcement of the penalty.

Due to the draft, if the Supreme Screener for Professional Liability, after analysing the judgement, becomes convinced that the practice of the profession of a physician punished abroad poses a threat to the safety of patients, he applies to the Regional Medical Court in Warsaw for take over for enforcement the judgement in Poland. The court would consider the motion in an open session. The motion should be considered immediately, not later than within 60 days from the date of its receipt. If a penalty is accepted for execution, the court would determine the legal qualification of the professional misconduct according to Polish law.

\section{Conclusions}

The analysis shows that it is possible to derive negative legal consequences for a physician or a dentist, who has the Polish right to practice the profession, in a situation where a violation of the law has been found in another country. 
First of all, a wide range of disciplinary responsibility of a physician and a dentist entitles the Polish medical self-government authorities to rule on disciplinary responsibility also for professional misconducts committed abroad. Such an interpretation is allowed by the provision of the art. 53 of the c.p.d., which does not limit liability to acts committed on the territory of the Republic of Poland. It should be emphasized that committing an act abroad for which a sanction by foreign medical court has been issued, may affect the warranty of proper and reliable practice in Poland.

Secondly, it should be noted that it is permissible to take over for enforcement the judgement of a foreign medical court in Poland by means of appropriate application of the provisions of the Code of Criminal Procedure. In accordance with art. 112, paragraph 1 of the c.p.d. to the extent not regulated by this legal act, the proper application of the provisions of the Code of Criminal Procedure, is allowed, including the regulations according to taking over for enforcement the judgment of the foreign court in Poland. So far, one procedure has been completed in this manner before the authorities of Polish medical chambers.

Thirdly, due to the increasing amount of information about physicians and dentists who have Polish right to practice their profession and who have been punished abroad, I believe it is justified to introduce into the provisions of the Law Act of 2 December 2009 on Chambers of Physicians and Dentists the legal regulations defining the procedure in such a situation. A solution allowing for a quick reaction of the Polish authorities seems to be very important.

\section{References}

Augustyniak, B. (2019). Postępowanie w sprawach karnych ze stosunków międzynarodowych. w: D. Świecki (red.), Meritum postępowanie karne. Warszawa: Wydawnictwo Wolters Kluwer. ISBN 9788381608053.

Gardocki, L. (2019). Prawo karne. Warszawa: Wydawnictwo C.H. Beck. ISBN 9788381587228.

Gubiński, A. (1993). Komentarz do Kodeksu Etyki Lekarskiej. Warszawa: Wydawnictwo Zakład Informacyjno-Wydawniczo-Kolportażowy Okręgowej Izby Lekarskiej w Warszawie. ISBN 8390076128. 
Izdebski, H. (2002). Sprawowanie pieczy nad należytym wykonywaniem zawodu przez samorządy zawodowe. w: S. Legat, M. Lipińska (oprac.), Zawody zaufania publicznego a interes publiczny - korporacyjna reglamentacja versus wolność wykonywania zawodu. Materiały z konferencji zorganizowanej przez Komisję Polityki Społecznej i Zdrowia Senatu RP przy współudziale Ministerstwa Pracy i Polityki Społecznej pod patronatem Marszałka Senatu RP Longina Pastusiaka. Warszawa. ISBN 838606532X.

Janicz. M. (2020). Przejęcie i przekazanie orzeczeń do wykonania. w: K. Dudka (red.), Kodeks postępowania karnego. Komentarz. Warszawa: Wydawnictwo Wolters Kluwer. ISBN 9788382230567.

Jóźwiak, P. (2016). Odpowiednie stosowanie w postępowaniu zawodowym lekarzy przepisów Kodeksu karnego. w: T. Gardocka, D. Jagiełło ( red.), Medyczne prawo karne. Warszawa: Wydawnictwo C.H. Beck. ISBN 9788325585617.

Konieczniak, P. (2016). O stosowaniu (i niestosowaniu) części ogólnej prawa karnego do odpowiedzialności zawodowej lekarzy. w: B. Namysłowska-Gabrysiak, K. Syroka-Marczewska, A. Walczak-Żochowska (red.), Prawo wobec problemów społecznych. Księga Jubileuszowa Profesor Eleonory Zielińskiej. Warszawa: Wydawnictwo C.H. Beck. ISBN 9788325585655.

Kowalski, P. (2017). Zawieszenie i pozbawienie prawa wykonywania zawodu lekarza przez sądy karne i sądy lekarskie w oparciu o orzeczenia wydane za granica. Medyczna Wokanda 9. ISSN 2081-4143.

Liszewska, A. (2016). Odpowiedzialność karna a odpowiedzialność zawodowa. w: J. Zajdel, (red.), Meritum prawo medyczne. Warszawa: Wydawnictwo Wolters Kluwer. ISBN 9788380921610.

Nowacki, J. (1964). „Odpowiednie” stosowanie przepisów prawa. Państwo i Prawo Nr 3. ISSN 0031-0980.

Rejman G. (1991). Odpowiedzialność karna lekarza. Warszawa: Wydawnictwo Uniwersytetu Warszawskiego. ISBN 8323007934.

Rużyłł, E. (1999). Etyka i Medycyna. Łomża: Oficyna Wydawnicza „Stopka”. ISBN 8385734309.

Sobczak, J. (2015). Zawody zaufania publicznego. Regulacja konstytucyjna i jej konsekwencje. w: J. Sobczak, J. Skrzypczak, M. Urbaniak (red.), Zawody zaufania publicznego? Wybrane zagadnienia odpowiedzialności zawodowej radców prawnych i lekarzy. Poznań: Wydawnictwo Nauka I Innowacje. ISBN 9788364864414.

Szewczyński, M. i Tomaszewska, P. (2017). IMI - mechanizm ostrzegania, Gazeta Lekarska Nr 4. ISSN 0867-2164. 
Szewczyński, M. i Tomaszewska, P. (2017). System IMI, Gazeta Lekarska 2017, Nr 3. ISSN 0867-2164.

Tomaszewska, P. (2019). Przewinienia zawodowe polskich lekarzy za granica. Jak powinien reagować samorzad lekarski. w: S. Hoc, D. Mucha (red.), Prawo i Medycyna. Wybrane zagadnienia. Opole: Wydawnictwo Scriptorium. ISBN 9788395578021.

Urbaniak, M. (2018). Przejęcie do wykonania w RP orzeczeń zagranicznych sq̨dów dyscyplinarnych $w$ sprawach odpowiedzialności dyscyplinarnej lekarzy. Medyczna Wokanda 11. ISSN 2081-4143.

Wrześniewska-Wal, I. (2018). Postępowanie przed sądami lekarskimi w praktyce. Warszawa: Wydawnictwo Wolters Kluwer. ISBN 9788381244848.

Zamroczyńska, M. (2018). Odpowiedzialność dyscyplinarna polskiego lekarza za delikty zawodowe popetnione na terytorium Wielkiej Brytanii. Medyczna Wokanda 10. ISSN 2081-4143.

Zielińska, E. (2001). Odpowiedzialność zawodowa lekarza i jej stosunek do odpowiedzialności karnej. Warszawa: Wydawnictwo Liber. ISBN 8372060630. Legal acts

Konstytucja Rzeczypospolitej Polskiej z dnia 2 kwietnia 1997 r., Dz.U.1997.78.483 ze zm.

Ustawa z dnia 5 grudnia 1996 r. o zawodach lekarza i lekarza dentysty, Dz.U. z 2020 r., poz. 514 ze zm.

Ustawa z dnia 6 czerwca 1997 r. Kodeks karny, Dz. U. z 2020 r., poz. 1444 ze zm.

Ustawa z dnia 6 czerwca 1997 r. Kodeks postępowania karnego, Dz. U. z 2020 r., poz. 30 ze zm.

Ustawa z dnia 2 grudnia 2009 r. o izbach lekarskich, Dz. U. z 2019 r., poz. 965 ze zm.

Dyrektywa 2005/36/WE Parlamentu Europejskiego i Rady z dnia 7 września 2005 roku w sprawie uznawania kwalifikacji zawodowych, Dz. Urz. WE L 255 z 30.09.2005, ze zm. 
